\title{
Fire models and methods to map fuel types: The role of remote sensing
}

\author{
Lara A. Arroyo , Cristina Pascual, Jose A. Manzanera \\ Technical University of Madrid (UPM), E.T.S.I. Montes (Universidad Politecnica de Madrid), Ciudad Universitaria s.n., 28040 Madrid, Spain
}

Keywords.

Forest fuels

Remote sensing

Fuel type

Fuel management

\begin{abstract}
A B S TRACT
Understanding fire is essential to improving forest management strategies. More specifically, an accurate knowledge of the spatial distribution of fuels is critical when analyzing, modelling and predicting fire behaviour. First, we review the main concepts and terminology associated with forest fuels and a number of fuel type classifications. Second, we summarize the main techniques employed to map fuel types starting with the most traditional approaches, such as field work, aerial photo interpretation or ecological modelling. We pay special attention to more contemporary techniques, which involve the use of remote

sensing systems. In general, remote sensing systems are low-priced, can be regularly updated and are less time-consuming than traditional methods, but they are still facing important limitations. Recent work nas n own that the integration of different sources of information and methods in a complementary way helps to overcome most of these limitations. Further research is encouraged to develop novel and enhanced remote sensing techniques.
\end{abstract}

\section{Contents}

1. Introduction

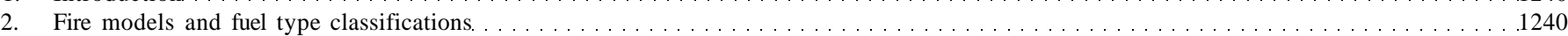

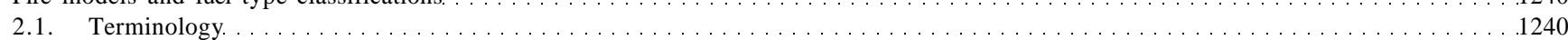

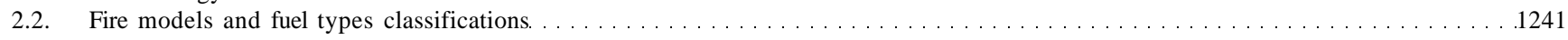

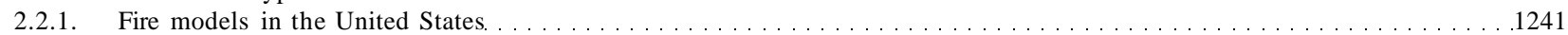

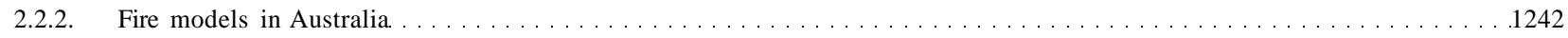

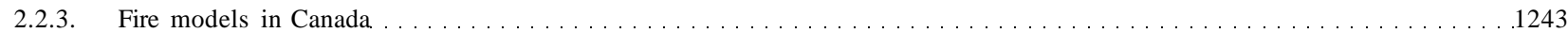

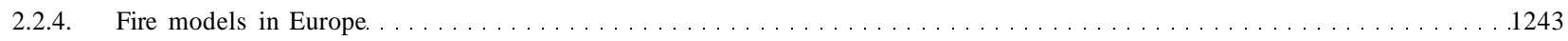

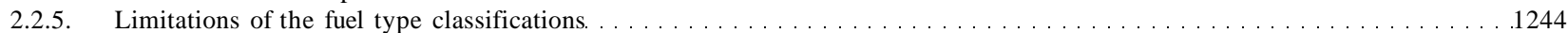

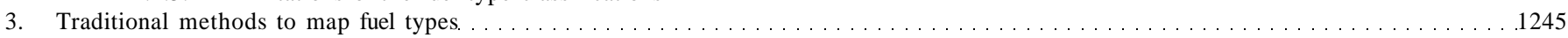

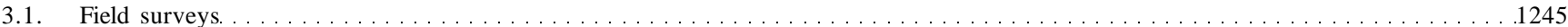

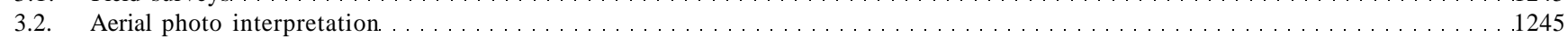

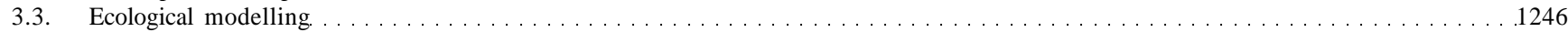

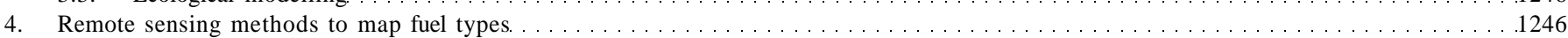

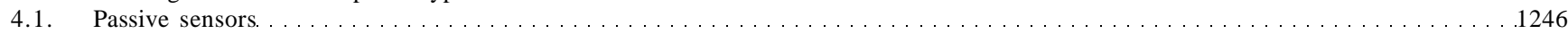

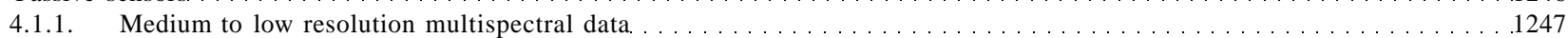


4.1.2. Very high resolution multispectral data

\section{Introduction}

The study of fire includes a broad spectrum of scientific disciplines including forestry, ecology, atmospheric chemistry (gas emissions), mechanical engineering (fire propagation patterns), and geography (spatial analysis of fire occurrence), to name just a few examples. The scales at which fires are studied also vary considerably, from global approaches where the goal is to better understand their contribution to the $\mathrm{CO}_{2}$ budget, to local scale studies where fire suppression or fire behaviour analysis may be the critical objective.

Wildland fires constitute a major environmental issue in a wide range of world ecosystems. In some cases, they can become a significant cause of land degradation (Maselli et al., 2000; Alloza et al., 2006; Fernandez et al., 2007). As a response to this concern, numerous studies have analyzed aspects related to fire behaviour, its suppression and effects (Barrett, 1988; Fryer and Johnson, 1988).

For forest fire management, an accurate knowledge of the fuel conditions has been shown to be critical, since they constitute a primary component of fire risk (Chuvieco et al., 2004). However, fuel conditions are normally complicated and difficult to describe. The fuel complex is composed of many types (life woody, dead woody and herbaceous) and sizes (1, 10, 100 and $1000 \mathrm{~h}$ ) of fuels (Keane et al., 2001). Considerable effort has been devoted to fuel characterization. Several fuel type classifications have been described and are currently employed by the different forest management services around the world.

Knowledge of the spatial distribution of these fuel types is also essential to developing management strategies. For example, during prescribed burning, lookout towers can be more efficiently placed when using accurate fuel type maps which provide information of fire danger conditions (Chuvieco et al., 1999). Moreover, accurate fuel type maps are a required input into programs which simulate fire behaviour. Fuel maps can be used at a variety of spatial and temporal scales. Fuel maps for strategic planning at regional scales require fuel type maps of large areas, while for local fire management may require more detailed procedures (Pausas and Vallejo, 1999).

As early as the mid-1960s, some authors predicted that remote sensors would revolutionize fuel type mapping (Adams, 1965). Since then, several remote sensing techniques have been developed towards that aim. Modern sensors have provided an even broader range of remote sensed imagery and novel parameters to analyse. Sensors can be classified as active, emitting their own energy to register a result, or passive, limited to recovering the electromagnetic energy originating from an external source such as the sun or the earth. Passive sensors include a broad range of systems generating many different image resolutions, qualities and prices. Within the active sensors, radar (working with compressed waves of length 0.1-1 m) has been traditionally used for fuel type mapping, while Light Detection and Ranging (LiDAR) has been used more recently.

In this paper we examine the most commonly used fuel classifications and methods for generating fuel maps. After reviewing some important definitions and the main fuel classification systems currently employed worldwide (second epigraph), we examine how fuel type maps can be obtained by traditional approaches (epigraph three); by means of remote sensing analysis (epigraph four) and by integrating different methods or sensors (fifth epigraph), a new promising trend in fuel mapping. We will review the main advances achieved in this subject and the principal drawbacks that need further development.

\section{Fire models and fuel type classifications}

\subsection{Terminology}

Imprecise use of certain terms regarding forest fuels often causes confusion and misunderstanding. It is worthwhile to briefly review the main ones. Fuels are defined in terms of the physical characteristics of the live and dead biomass that contribute to the spread, intensity and severity of wildland fire (Burgan et al., 1998; Andrews and Queen, 2001). Examples include loading (weight per unit area), size (particle diameter), and bulk density (weight per unit volume).

Because it is difficult to describe all physical characteristics for all fuels in an area, the description of those properties relevant to fire danger estimation and fire propagation studies is based on classification schemes, which summarize large groups of vegetation characteristics. These groups are usually called fuel types (Pyne et al., 1996). More specifically, a fuel type has been defined as "an identifiable association of fuel elements of distinctive species, form, size arrangement, and continuity that will exhibit characteristic fire behaviour under defined burning conditions" (Merrill and Alexander, 1987).

We use the term fire model to mean mathematical relationships that describe the potential characteristics of a fire. Fire models are often informally referred to as fire behaviour models, fire effects models, or smoke models. According to Andrews and Queen (2001) fuel models are sets of parameters required by the associated fire model. In other words, fire models are equations and fuel models are lists of numbers that describe the fuel types as required by the fire model. Thus, a fuel model is the numerical description of the physical parameters that characterize each fuel type. Fuel types may be similar in different ecosystems, but may have different fuel models associated with them (Chuvieco et al., 2003).

Fire models become especially useful to managers when they are packaged into decision support systems (Andrews and Queen, 2001). This packaging varies in accordance with fire management needs. For example, the BEHAVE (Fire behavior prediction and fuel modelling system) (Andrews, 1986) and the FARSITE Fire area simulator (FARSITE) (Finney, 1998) are decision support systems comprised of essentially the same mathematical models (spread rate, intensity, fuel moisture, spotting distance). Users of BEHAVE interactively provide input to produce tables and graphs, while users of FARSITE supply Geographical Information Systems (GIS) data layers and weather files to produce spatial maps of fire growth and intensity. 
Table 1

NFDRS fuel classification system, according to Cohen and Deeming (1982)

\begin{tabular}{|c|c|c|c|c|c|c|c|c|c|}
\hline \multirow[t]{3}{*}{ Fuel type } & \multirow[t]{3}{*}{ Fuel model } & \multicolumn{8}{|c|}{ Fuel parameters } \\
\hline & & \multicolumn{6}{|c|}{ Fuel loadings (t/acre) } & \multirow[t]{2}{*}{ Fuel depth (ft) } & \multirow{2}{*}{$\begin{array}{l}\text { Moisture of extinction } \\
\text { dead fuels }(\%)\end{array}$} \\
\hline & & $1 \mathrm{~h}$ & $10 \mathrm{~h}$ & $100 \mathrm{~h}$ & $1000 \mathrm{~h}$ & Wood & Herb & & \\
\hline Western grasses (annual) & A & 0.2 & & & & & 0.3 & 0.8 & 15 \\
\hline Western grasses (periannial) & $\mathrm{L}$ & 0.25 & & & & & 0.5 & 1.0 & 15 \\
\hline Sawgrass & $\mathrm{N}$ & 1.5 & 1.5 & & & 2.0 & & 3.0 & 25 \\
\hline Pine-grass savanna & $\mathrm{C}$ & 0.4 & 1.0 & & & 0.5 & 0.8 & 0.75 & 10 \\
\hline Southern rough & $\mathrm{D}$ & 2.0 & 1.0 & & & 3.0 & 0.75 & 2.0 & 30 \\
\hline Sagebrush-grass & $\mathrm{T}$ & 1.0 & 0.5 & & & 2.5 & 0.5 & 1.25 & 15 \\
\hline California chaparral & $\mathrm{B}$ & 3.5 & 4.0 & 0.5 & & 11.5 & & 4.5 & 15 \\
\hline Intermediate brush & $\mathrm{F}$ & 2.5 & 2.0 & 1.5 & & 9.0 & & 4.5 & 15 \\
\hline Hardwood litter (winter) & $\mathrm{E}$ & 1.5 & 0.5 & 0.25 & & 0.5 & 0.5 & 0.4 & 25 \\
\hline Southern pine plantation & $\mathrm{P}$ & 1.0 & 1.0 & 0.5 & & 0.5 & 0.5 & 0.4 & 30 \\
\hline Hardwood litter (summer) & $\mathrm{R}$ & 0.5 & 0.5 & 0.5 & & 0.5 & 0.5 & 0.25 & 25 \\
\hline Western pines & $\mathrm{U}$ & 1.5 & 1.5 & 1.0 & & 0.5 & 0.5 & 0.5 & 20 \\
\hline Heavy slash & I & 12.0 & 12.0 & 10.0 & 12.0 & & & 2.0 & 25 \\
\hline Intermediate slash & $\mathbf{J}$ & 7.0 & 7.0 & 6.0 & 5.5 & & & 1.3 & 25 \\
\hline Light slash & $\mathrm{K}$ & 2.5 & 2.5 & 2.0 & 2.5 & & & 0.6 & 25 \\
\hline High pocosin & 0 & 2.0 & 3.0 & 3.0 & 2.0 & 7.0 & & 4.0 & 30 \\
\hline Tundra & $\mathrm{S}$ & 0.5 & 0.5 & 0.5 & 0.5 & 0.5 & 0.5 & 0.4 & 25 \\
\hline Short-needle conifer (normal dead) & $\mathrm{H}$ & 1.5 & 1.0 & 2.0 & 2.0 & 0.5 & 0.5 & 0.3 & 20 \\
\hline Short-needle conifer (heavy dead) & G & 2.5 & 2.0 & 5.0 & 12.0 & 0.5 & 0.5 & 1.0 & 25 \\
\hline Alaskan black spruce & Q & 2.0 & 2.5 & 2.0 & 1.0 & 4.0 & 0.5 & 3.0 & 25 \\
\hline
\end{tabular}

\subsection{Fire models and fuel types classifications}

\subsubsection{Fire models in the United States}

One of the most widely used fire models is Rothermel's (1972), which simulates fire spread in surface fuels. It was developed as a result of a 1968 plan for a complete fire danger rating system. The results were Rothermel's fire spread model and the National Fire Danger Rating System (NFDRS) (Deeming et al., 1972). This model is the basis for many decision support systems in North America, including the NFDRS, BEHAVE, FARSITE and the National Fire Management Analysis System (NFMAS) for economic planning (Lundgren et al., 1995).

The NFDRS (Deeming et al., 1972, 1977) constitutes a broad scale fire danger system. It is basically a seasonal weather system, which depends upon an ordered set of weather records to establish conditions of the day. These weather conditions along with the
NFDRS fuel models are used to represent the day-to-day and seasonal trends in fire danger or fire potential for large areas. NFDRS developers agreed that a highly sophisticated description of fuels for NFDRS was not necessary because there is more variability in a rating area than could be accounted for. There were originally nine fire fuel types (Deeming et al., 1972), that were expanded to 20 in 1978 (Deeming et al., 1977). A detailed description of the evolution of this fire danger system can be found at Hardy and Hardy (2007). Table 1 shows the NFDRS fuel types. This fire danger system considers two mayor groups of fuel moisture models: live and dead. The live fuels are further classified into herbaceous and woody shrub. The 1-, 10-, 100-, and 1000-h time-lag classes represent the dead fuels (Cohen and Deeming, 1982).

In the context of local scale fire behaviour, the BEHAVE system uses a different fuel type classification, known as the NFFL (Northern Forest Fire Laboratory) or Behave fuel types (Albini,

Table 2

NFH fuel classification system (from Andrews, 1986)

\begin{tabular}{|c|c|c|c|c|c|c|c|}
\hline \multirow[t]{3}{*}{ Fuel type } & \multirow[t]{3}{*}{ Fuel model } & \multicolumn{6}{|c|}{ Fuel ]parameters } \\
\hline & & \multicolumn{4}{|c|}{ Fuel]loadings (t/ha) } & \multirow[t]{2}{*}{ Fuel depth (ft) } & \multirow{2}{*}{$\begin{array}{l}\text { Moisture of extinction } \\
\text { dead fuels }(\%)\end{array}$} \\
\hline & & $1 \mathrm{~h}$ & $1 \mathrm{Oh}$ & $100 \mathrm{~h}$ & Life & & \\
\hline \multicolumn{8}{|l|}{ Grass and grass-dominated } \\
\hline Short grass $(30 \mathrm{~cm})$ & 1 & 0.74 & & & & 1.0 & 12 \\
\hline Timber & 2 & 2.00 & 1.00 & 0.50 & 0.50 & 1.0 & 15 \\
\hline Tall grass $(76 \mathrm{~cm})$ & 3 & 3.01 & & & & 2.5 & 25 \\
\hline Chaparral and shrub fields & & & & & 5.01 & & \\
\hline Chaparral $(18 \mathrm{~cm})$ & 4 & 5.01 & 4.01 & 2.00 & 2.00 & 6.0 & 20 \\
\hline Brush $(61 \mathrm{~cm})$ & 5 & 1.00 & 0.50 & & & 2.0 & 20 \\
\hline Dormant brush, hardwood slash & 6 & 1.50 & 2.50 & 2.00 & 0.37 & 2.5 & 25 \\
\hline Southern rough & 7 & 1.13 & 1.87 & 1.50 & & 2.5 & 40 \\
\hline \multicolumn{8}{|l|}{ Timber litter } \\
\hline Closed timber litter & 8 & 1.50 & 1.00 & 2.50 & & 0.2 & 30 \\
\hline Hardwood litter & 9 & 2.92 & 0.41 & 0.15 & & 0.2 & 25 \\
\hline Timber (litter and understory) & 10 & 3.01 & 2.00 & 5.01 & 2.00 & 1.0 & 25 \\
\hline \multicolumn{8}{|l|}{ Slash } \\
\hline Light logging slash & 11 & 1.50 & 4.51 & 5.51 & & 1.0 & 15 \\
\hline Medium logging slash & 12 & 4.01 & 14.03 & 16.53 & & 2.3 & 20 \\
\hline Heavy jogging slash & 13 & 7.01 & 23.04 & 28.05 & & 3.0 & 25 \\
\hline
\end{tabular}


1976; Burgan and Rothermel, 1984). The authors distinguished 13 fuel types based on the primary nature of the surface fuel (Table 2). These fuel models are divided into four vegetation groups: herbaceous fuels (fuel types 1-3); shrubs (fuel types 4-6); dead leaves under forest canopy (fuel types 8-10); and slash residues and basal accumulation material (fuel types 11-13). In addition to these 13 standard fuel types, managers have the option of developing custom fuel types. This classification strategy has been widely used in fire propagation studies across many different ecosystems.

FARSITE Fire Area Simulator employs the same NFFL fuel types developed for the BEHAVE system. This decision support system, developed by Finney (1998), includes models for crown fire behaviour as well as surface fuel models. It therefore requires specific information of crown fuel parameters such as percentage canopy cover, canopy height, crown base height and crown bulk density. One of the advantages of the FARSITE system is its spatial scope. The models are integrated using a vector propagation technique for fire perimeter expansion that controls both space and time resolution of fire growth over the landscape. Thus, the system produces vector fire perimeters (polygons) at specified time intervals (Finney, 2004). All input layers are geographical variables and are therefore easily linked to GIS and remote sensing.

A newer fuel classification system in the Unites States is the Fuel Characteristics Classification System (FCCS), which enables the user to create and catalogue fuelbeds and to classify them according to their capacity to support fire and consume fuels (Sandberg et al., 2001; Ottmar et al., 2007). The FCCS defines a fuelbed as a relatively homogeneous unit on the landscape, representing a unique combustion environment (Ottmar et al., 2007). The model stratifies fuelbeds into six horizontal fuelbed strata. Each fuelbed stratum (tree canopy, shrub, low vegetation, woody fuel, litter fuel and ground fuel) is divided into two or more categories, which show common combustion characteristics. The system allows the creation and modification of these spatial data layers, inferring quantitative fuel characteristics (physical, chemical and structural properties) and probable fire parameters specific to each described fuelbed. In addition, the system provides the NFFL and NFDRS fuel assignment, what makes the conceptual framework applicable worldwide (Ottmar et al., 2007).

\subsubsection{Eire models in Australia}

There are several decision support systems used in Australia by the various states and private land management agencies and the coordinating rural fire authorities. The most widely used are the McArthur Forest Fire Danger Rating System and McArthur Grassland Fire Danger Rating System, which were devised by Alan McArthur in the 1960s (McArthur, 1966, 1967). Based on the meters used in the USA in the 1950s, he developed two meters for estimating fire danger in grassland and forest vegetation types (shown in Fig. 1). The indices are indicative of probability of ignition, the expected spread rate and the difficulty of containment, and they are dependent on temperature, relative humidity and wind speed. They describe the relative danger from day-to-day and are used to give an indication of fire danger over a large area. Although they were originally in the form of tables or meters, these models have been transformed into equations to enable computer prediction of danger rating and fire behaviour (Noble, 1980; Sirakoff, 1985).

A more systematic but similar approach is used in Western Australia. Here, the result of years of fire behaviour experience has been condensed into the Forest Fire Behaviour Tables (Sneeuwjagt and Pee, 1985). In this case there are again two fuel types for which fire danger indices are calculated: the northern jarrah dry sclerophyll forest, dominated by Eucalyptus marginata and the southern karri wet sclerophyll forest, dominated by Eucalyptus diversicolor

Both Australian fire models were developed by correlating fire behaviour from experimental fires and opportunistic observation of wildfires with fuel and weather parameters (Cheney and Gould,

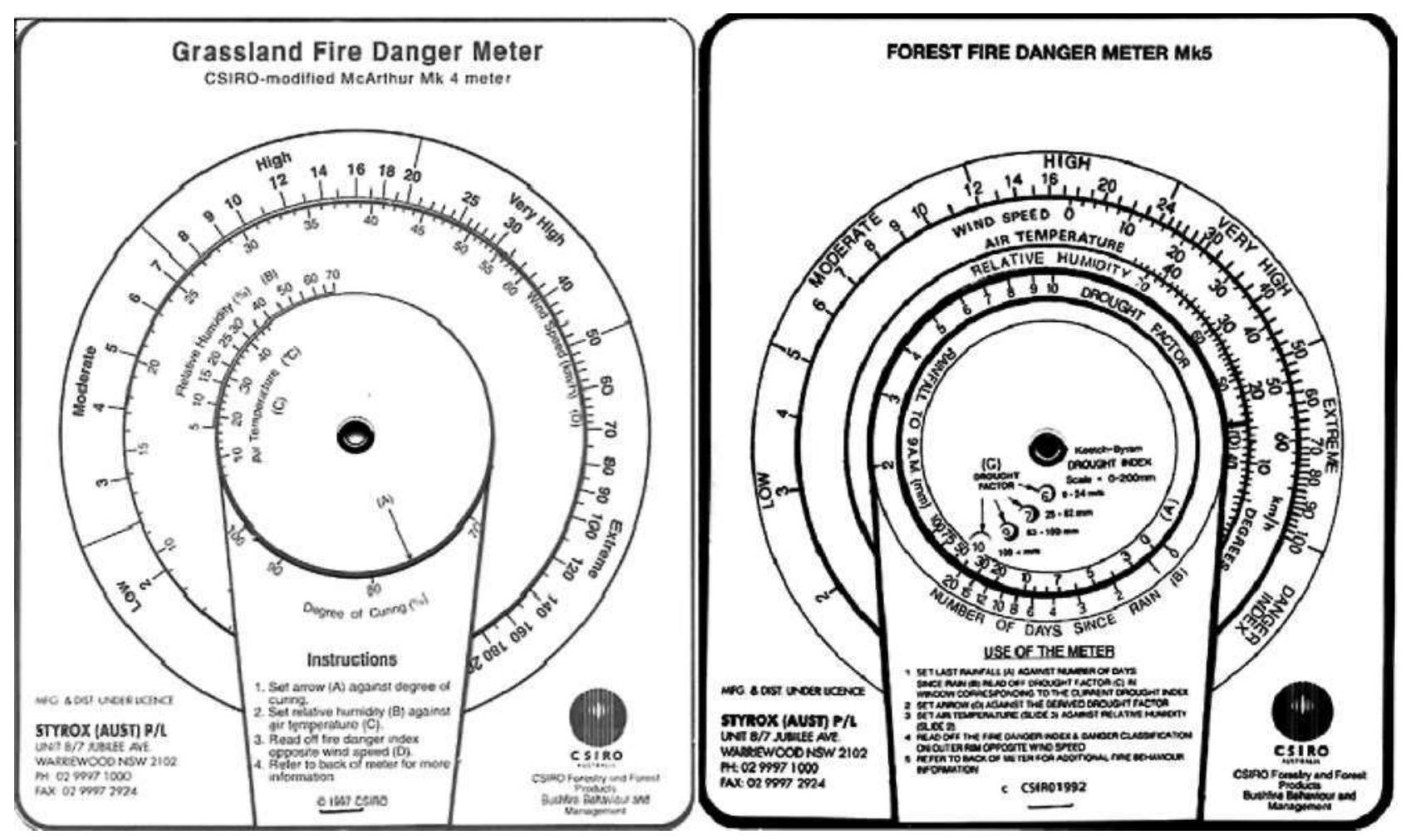

Fig. 1. Australian McArthur Fire Danger Meter for forest (left) and grassland (right). 
Table 3

FBP system fuel types (from Forestry Canada, 1992)

\begin{tabular}{|c|c|c|}
\hline Group & Identifier & Fuel type description \\
\hline Coniferous & $\begin{array}{l}\text { C- } 1 \\
\text { C }-2 \\
\text { C }-3 \\
\text { C }-4 \\
\text { C }-5 \\
\text { C }-6 \\
\text { C }-7\end{array}$ & $\begin{array}{l}\text { Spruce-lichen woodland } \\
\text { Boreal spruce } \\
\text { Mature jack or lodgepole pine } \\
\text { Immature jack or lodgepole pine } \\
\text { Red and white pine } \\
\text { Conifer plantation } \\
\text { Ponderosa pine-Douglas-fir }\end{array}$ \\
\hline Deciduous & D- 1 & Leafless aspen \\
\hline Mixedwood & $\begin{array}{l}M-1 \\
M-2 \\
M-3 \\
M-4\end{array}$ & $\begin{array}{l}\text { Boreal mixedwood-leafless } \\
\text { Boreal mixedwood-green } \\
\text { Dead balsam fir mixedwood-leafless } \\
\text { Dead balsam fir mixedwood-green }\end{array}$ \\
\hline Slash & $\begin{array}{l}S-1 \\
S-2 \\
S-3\end{array}$ & $\begin{array}{l}\text { Jack or lodgepole pine slash } \\
\text { White spruce-balsam slash } \\
\text { Coastal cedar-hemlock-Douglas-fir slash }\end{array}$ \\
\hline Open & $0-1$ & Grass \\
\hline
\end{tabular}

1996). In both cases, the models only apply to only two fuel types. For other fuels new models have to be developed, as was the case for widespread buttongrass moorland vegetation in Tasmania (see Marsden-Smedley and Catchpole, 1995a,b, 2001; Marsden-Smedleyetal., 2001).

\subsubsection{Fire models in Canada}

The decision support systems in Canada were also developed from experimental fires and wildfires, but apply to all vegetation and are quite more complex than the Australian ones. The current form of the Canadian Forest Fire Danger Rating System (CFFDRS) is made up of two major subsystems that have been used throughout Canada for a number of years: the Canadian Fire Weather Index (FWI) System (van Wagner and Pickett, 1985; van Wagner, 1987) and the Canadian Fire Behaviour Prediction (FBP) System (Forestry Canada, 1992). The FBP system is based on simple mathematical models and they are partly based on physical and experimental models. Fire behaviour models for spread rate and fuel consumption in this system were derived from a database of over 400 experimental, wild and prescribed fire observations. The system organizes fuels into five major groups (coniferous, deciduous, mixedwood, slash and open), with a total number of 16 discrete fuel types (Lawson et al., 1985). These fuel types are used to describe fire behaviour characteristics that would be expected undervarious burning conditions. Fuel types in the FBP system are described qualitatively, using stand structure and composition, surface and ladder fuels, and the specific forest floor cover and organic (duff) layer present. The mayor FBP fuel types are summarized in Table 3.

\subsubsection{Fire models in Europe}

European researchers developed a new fuel classification system called Prometheus, which simplifies and adapts the NFFL classification to Mediterranean conditions. This fuel classification system is intended to be better adapted to fuels found in Mediterranean ecosystems. The main criterion of classification in this system is the type and height of the propagation element divided into three major groups: grass, shrubs or ground litter. Fuel types are therefore described according to the spatial distribution of these three major groups. Fire behaviour is then modelled by taking into account fuel height and density (Riano et al., 2002). This classification system comprises seven fuel types (Fig. 2).
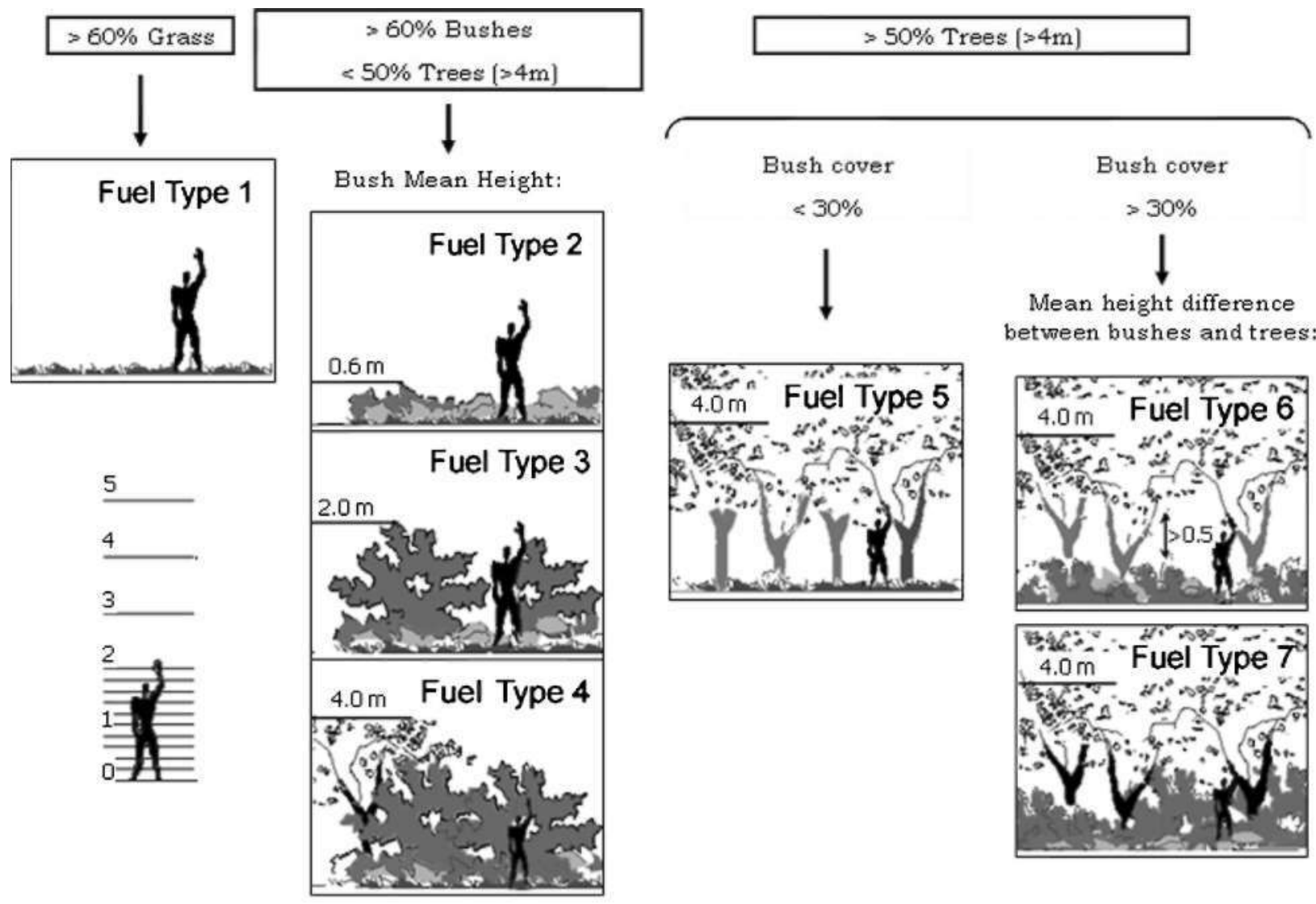

Fig. 2. PROMEIHEUS fuel types (Arroyo et al., 2006). 
Table 4

Properties of the main fuel classification systems

\begin{tabular}{|c|c|c|c|c|}
\hline Fuel classification system & Number of fuel types & Decision support system \fire model & Country of application & System description \\
\hline NFDRS fuel types & 20 & NFDRS/Rothermel's fire spread model & USA & Broad scale fire danger system \\
\hline NFFL fuel types & $13^{\mathrm{a}}$ & $\begin{array}{l}\text { BEHAVE and FARSITE } \\
\text { Rothermel's fire spread model }\end{array}$ & USA & $\begin{array}{l}\text { BEHAVE: Local scale fire behaviour } \\
\text { FARSITE: Incorporates crown fire behaviour }\end{array}$ \\
\hline FCCS & $216^{\mathrm{b}}$ & $\begin{array}{l}\text { Fire behaviour models } \\
\text { Fire effects models }\end{array}$ & USA & $\begin{array}{l}\text { Conceptual framework for constructing fuel } \\
\text { classifications }\end{array}$ \\
\hline McArthur fuel types & 3 & $\begin{array}{l}\text { McArthur Fire Danger Rating System } \\
\text { (forest and grassland systems) }\end{array}$ & Australia & $\begin{array}{l}\text { Meters for estimating fire danger on } \\
\text { a day-to-day base }\end{array}$ \\
\hline FBP fuel types & 16 & Canadian FBP System & Canada & $\begin{array}{l}\text { To describe fire behaviour } \\
\text { Developed form experimental fires } \\
\text { and wildfires }\end{array}$ \\
\hline Prometheus fuel types & 7 & Rothermel's fire spread model & Europe $^{\mathrm{c}}$ & $\begin{array}{l}\text { Based on the NFFL } \\
\text { Adapted to Mediterranean conditions }\end{array}$ \\
\hline
\end{tabular}

${ }^{\text {a }}$ Option of developing custom fuel types.

b New fuelbeds added periodically.

c Mediterranean countries.

Other European countries with different weather conditions have also developed their own fuel classification system. For instance, in the case of Switzerland, Harvey et al. (1997) applied an adapted version of the US Forest Service method for developing surface fuel models (Brown et al., 1982) to the Swiss Alps. Six fuel models were derived, mapped and run in Rothermel's fire spread model. Other fire danger rating systems have been developed for the United Kingdom and Portugal (Fernandes et al., 2006; Kitchen et al., 2006).

\subsubsection{Limitations of the fuel type classifications}

As can be seen from the previous sections several fuel type classifications have been developed around the world (Table 4 summarizes their characteristics). However, fuels are not easy to classify. They are structurally complex and vary widely in their physical attributes, their fire behaviour and effects, as well as in the options they present for fire control and use. Several authors (for example, Scott, 1999; Keane et al., 2001; Sandberg et al., 2001; Hall and Burke, 2006) have pointed out the limitations of the different fuel models. Here, we summarize the main ones.

2.2.5.1. Fuel models are site-specific. Each fuel type classification is only applicable for similar geographic locations and cannot be used for other environments. Moreover, when foreign systems have been adopted for different locations the results have been poor.

Table 5

Physical description similarity chart of NDRS and NFLL fuel models (from Anderson, 1982)

\begin{tabular}{|c|c|c|c|c|c|c|c|c|c|c|c|c|c|c|}
\hline & \multicolumn{13}{|c|}{ NFFL FUEL MODELS } \\
\hline & & 1 & 2 & 3 & 4 & 5 & 6 & 7 & 8 & 9 & 10 & 11 & 12 & 13 \\
\hline \multirow{20}{*}{ 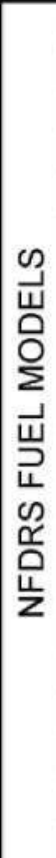 } & $\bar{A}$ & $\bar{x}$ & & & & & & & & & & & & \\
\hline & $\bar{L}$ & $\bar{x}$ & & & & & & & & & & & & \\
\hline & S & $X$ & & & & & 3rd & & & 2nd & & & & \\
\hline & C & & $x$ & & & & & & & 2nd & & & & \\
\hline & $T$ & & $x$ & & & 3rd & 2nd & & & & & & & \\
\hline & $\bar{N}$ & & & $\bar{X}$ & & & & & & & & & & \\
\hline & $B$ & & & & $\bar{x}$ & & & & & & & & & \\
\hline & 0 & & & & $\mathrm{x}$ & & & & & & & & & \\
\hline & $F$ & & & & & 2nd & $\bar{x}$ & & & & & & & \\
\hline & Q & & & & & & $\mathrm{X}$ & 2nd & & & & & & \\
\hline & $\bar{D}$ & & & & & & 2nd & $\bar{x}$ & & & & & & \\
\hline & $\mathrm{H}$ & & & & & & & & $\mathrm{X}$ & & & & & \\
\hline & $\mathrm{R}$ & & & & & & & & $\mathrm{X}$ & & & & & \\
\hline & $\bar{U}$ & & & & & & & & & $\bar{X}$ & & & & \\
\hline & $P$ & & & & & & & & & $x$ & & & & \\
\hline & $E$ & & & & & & & & & $\bar{X}$ & & & & \\
\hline & $\bar{G}$ & & & & & & & & & & $\mathrm{X}$ & & & \\
\hline & $\mathrm{K}$ & & & & & & & & & & & $x$ & & \\
\hline & $\mathrm{J}$ & & & & & & & & & & & & $X$ & \\
\hline & $T$ & & & & & & & & & & & & & $\mathrm{X}$ \\
\hline
\end{tabular}


Fogarty et al. (1998), for example, discuss the problems of adopting the Canadian system for New Zealand.

2.2.5.2. Limited applicability. A fuel classification can only be applied for the specific aims that were considered during its development. Because fuel classifications are designed for specific software applications, they only include the portion of the fuel component required by the program they were designed to support. Most fire behaviour fuel models are limited to the prediction of fire behaviour and they do not quantify the fuel characteristics needed for other applications (Keane et al., 2001). Moreover, although they may work well for predicting the rate of spread and the intensity of natural fires during the peak fire season, they are deficient for other purposes, such as predicting the behaviour of prescribed fires or the transition to crown (Scott and Burgan, 2005). Also, most fuel models are not particularly useful for predicting fire effects that are dependent on fire residence time, such as soil or cambium heating, or effects on the atmosphere, such as air pollutant or carbon release, that depend on biomass consumption (Sandberg et al., 2001).

\subsubsection{Confusion between different classification systems. The fact} that there are 20 standard NFDRS fuel models as well as 13 standard fire behaviour models (NFFL) in the USA has caused confusion (Andrews, 1986). Both systems are based on Rothermel's fire spread model, but the development and application of these systems are different. Therefore, the sets of numbers that represent the fuels for each set of equations (i.e. the fuel models) are necessarily different. Anderson (1982) presented a "Physical Description of Similarity Chart of NFDRS and BEHAVE fire behaviour fuel models" giving a correspondence between the 20 NFDRS fuel models and the 13 NFFL fire behaviour fuel models (Table 5). As indicated by the title of the chart, this correlation was primarily based on a physical description of the fuels and must be considered with care. In addition, when the two sets of fuel models were later correlated by ranking the rate of spread to intensity, different values were obtained (Andrews, 1986). The great variety of fuel, weather and site conditions that exists in the field means that the user should take these factors into consideration and adjust his predictions accordingly (Anderson, 1982).

2.2.5.4. Difficult to map. Although fuel maps are essential to fire management at many spatial and temporal scales, mapping them is difficult and costly (Keane et al., 2001; Rollins et al., 2004). The high fuel variability across time and space is probably the main condition that confounds an accurate fuel mapping, although there are other factors that limit the ability to map fuel types. The main ones will be discussed in the next sections, which concentrate on the methods used to map fuel types. A more detailed description of the reasons why mapping fuels is challenging can be found in Keane et al. (2001).

\section{Traditional methods to map fuel types}

As previously discussed, fuel types are in general difficult to assess and map. Therefore, selecting an appropriate mapping method is as important as employing an adequate fuel classification scheme. Different scales and objectives may lead to different combinations of classification schemes and methods. The following two sections focus on the mapping methods that have been developed and employed for this purpose.

\subsection{Field surveys}

Historically, the first efforts in mapping fuel types were based on field surveys. Field reconnaissance involves traversing a landscape on the ground and recording the extent of similar fuel conditions in notebooks or on paper maps. Remarkably, Hornby (1935) mapped more than 6 million ha in the northern Rocky Mountains using over 90 workers who walked, rode, or drove through national forest lands and described fuel conditions by colouring polygons on maps. The fuel types were classified as a function of the rate of spread and resistance to control. Hornby's work stands out because of its enormous scope and human effort.

The difficulty of conducting a ground survey is also evident in the work carried out by Show and Kotok (1929), who dedicated 10 years of field work to obtain an 8-class vegetation map covering 6108 ha in Northern California (USA). In addition, the authors admitted that their work was not concluded. Considering that fuel type maps should be updated periodically, this task becomes very problematic to accomplish in this fashion. More recently, fuel has been mapped through extensive field inventory with sampling and statistical inference (Miller et al., 2003). Although these techniques were successful, the amount of time and money required render their implementation impractical for many land managers (Falkowski et al., 2005).

The principal advantage of field surveys is that the researcher is in physical contact with the fuel and therefore fuels are mapped from actual conditions observed on the ground. Mapping error is limited to erroneous fuel type assessments or improper stand delineations on paper maps. Due to the complexity of vegetation characteristics, discrimination of a fuel type at a detailed level requires a great field effort. Consequently, field surveys are still indispensable for fuel type mapping either as the basic source of data or for assessment of products generated at a lower level of detail or to parameterise each fuel type. This approach is also recommended to create field reference datasets (i.e. groundtruth) to validate maps created from remotely sensed data products.

\subsection{Aerial photo interpretation}

The limitations of fieldwork in terms of spatial coverage and cost led to the development of other methods for operational fuel type mapping. The growing use of aerial photography for natural resource mapping during the 1940 s and 1950 s provided a good alternative to field surveys. Lee (1941) was among the first to propose the use of photo interpretation techniques to discriminate fuel types in aerial photography, although he also pointed out some limitations, such as confusion caused by illumination differences.

Natural-colour photography was later introduced to improve vegetation mapping (Lund, 1969) providing more accurate discrimination of species composition and cover type (Scott et al., 2002). Infrared-colour photographs have also been used as they provide relevant spectral information for the discrimination of fuel types. For example, Bertolette and Spotskey (1999) used photo interpretation of infrared-colour aerial photographs combined with extensive fieldwork to produce a detailed inventory of fuel properties such as canopy cover, tree height, crown base height and crown bulk density, that are required for the new 3D fire simulation models (Scott, 1999).

Because it is a reliable approach, aerial photo interpretation has become one of the most commonly used techniques for mapping vegetation and fuel types. Even though it is more time-consuming than newer approaches, aerial photo interpretation is a good compromise between costs and precision, particularly when working at fine scales. As a consequence, it is currently widely employed by governmental agencies and forest managers (James et al., 2007). 


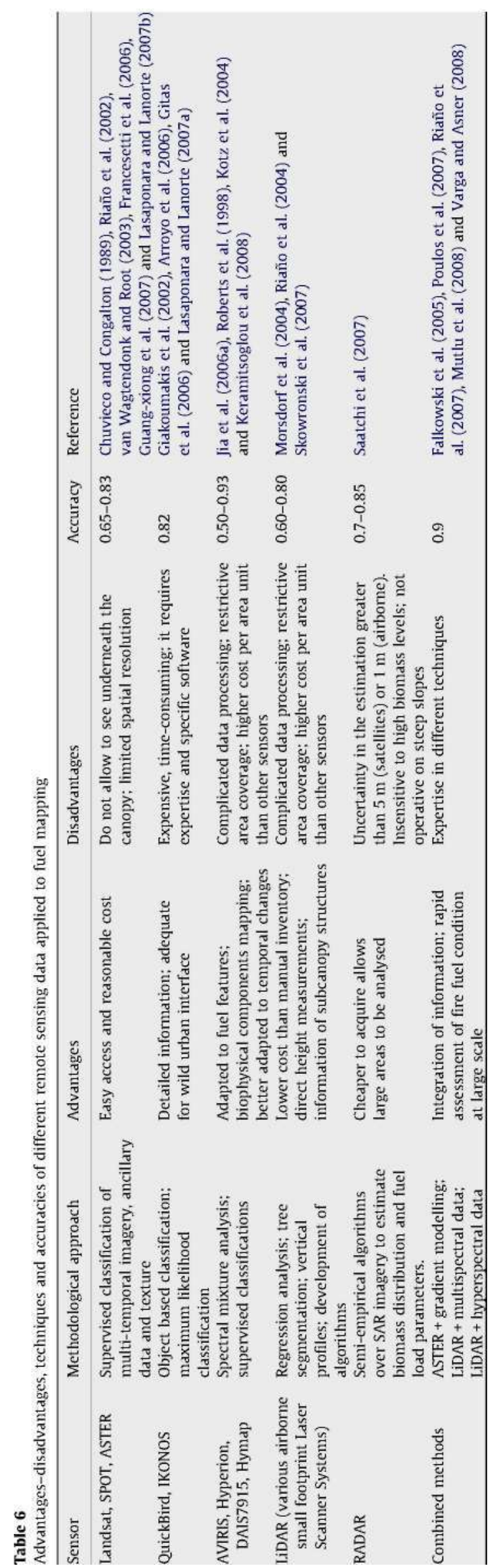

\subsection{Ecological modelling}

The modelling approach uses environmental gradients and biophysical modelling to create fuel maps. Environmental gradients are biogeochemical phenomena, such as climate and topography, that directly influence vegetation and fuel dynamics. Biophysical modelling uses ecosystem dynamic models to quantify these gradients across a landscape (Keane et al., 2001). At a minimum, the environmental data should include the biophysical setting (e.g. potential vegetation type), species composition (e.g. cover type), and vertical stand structure (e.g. structural stage) (Keane et al., 1998). Fuel models are then assigned to combinations of the environmental variables using field data and expert opinion.

The value of this approach is that gradients provide an ecological context in which to understand, explore, and predict fuel dynamics. Low fuel loading in a stand, for example, may be explained by low precipitation, high evapotranspiration, and shallow soils. One problem is that biophysical gradients do not provide a complete description of existing biotic conditions, so an alternative approach is often needed to spatially portray vegetation-based gradients. Another disadvantage is that ecological modelling requires abundant field data, complex ecosystems models and intensive statistical analysis. On the other hand, once a gradient framework is established, it can be used for other locations.

\section{Remote sensing methods to map fuel types}

Remote sensing offers a wide range of different sensors and algorithms that can assist fuel mapping. In this section we present the different approaches adopted in remote sensing to map fuel types, grouped according to the kind of sensor employed. Table 6 summarizes the advantages and limitations of each method, as well as the levels of accuracy obtained for each case. Many of the challenges and difficulties highlighted by Keane et al. (2001) are still present (e.g. the inherent complexity of fuel types and their high variability across space and time). Nevertheless, the recent incorporation of new sensors and improved algorithms show promising advances and increased levels of accuracy.

\subsection{Passive sensors}

Fuel type mapping from multispectral remote sensed data has been attempted by several authors. Most commonly, these studies have been based on medium-resolution sensors, such as SPOT-HRV (Systeme Pour l'Observation de la Terre - Haute Resolution Visible), Landsat MSS (Multispectral Scanner) orTM (Thematic Mapper) (De Wulf et al., 1990; Salas and Chuvieco, 1995; Castro and Chuvieco, 1998; Maselli et al., 2000; van Wagtendonk and Root, 2003). In the last years, the development of new sensors with higher resolutions has also allowed the study of forest fuels at smaller scales (Giakoumakis et al., 2002; Arroyo et al., 2005, 2006; Gitas et al., 2006; Lasaponara and Lanorte, 2007a).

The most important limitation of these optical images (i.e. Landsat, SPOT, IKONOS, etc.) is their inability to penetrate forest canopies (Keane et al., 2001). These sensors are usually unable to detect surface fuels where more than two canopies are present. Furthermore, when sensors are able to view the ground, as in stands with open crowns, it is difficult to distinguish between surface fuel sizes and categories using standard image processing techniques (Keane et al., 2001; Rollins et al., 2004). Additionally, reflectance is not directly related to vegetation height, which is a critical variable to discriminate fuel types. All these limitations have led to the development of alternative procedures and systems, which include the integration of gradient modelling 
and remote sensing; the combination of more than one sensor and/ or the use of newer sensors, such as LiDAR, or very high resolution (VHR) imagery.

\subsubsection{Medium to low resolution multispectral data}

Most medium to low resolution multispectral approaches characterize surface fuels by classifying an image into vegetation categories and then assigning fuel characteristics to each category. For example, the pioneering work of Kourtz (1977) introduced the main techniques of digital fuel type classification using satellite remote sensing images (Landsat-MSS): supervised classification (maximum likelihood), unsupervised classification, and principal components. He obtained nine fuel type classes within his study area located northwest of Ottawa (Quebec, Canada). He employed multitemporal images to take advantage of the temporal variability among fuel types (Chuvieco et al., 2003). Fuel types were also assigned to vegetation categories applying maximum likelihood decision rules to Landsat MSS data across Wood Buffalo National Park, Canada (Wilson et al., 1994). Chuvieco and Congalton (1989), Chuvieco and Salas (1996) and Castro and Chuvieco (1998) characterized fuel types through the classification of Landsat TM and SPOT data in Spain and Chile. The accuracies obtained from these studies ranged from $65 \%$ to $80 \%$ (Chuvieco et al., 1999).

Alternative approaches have also been developed. In California, chaparral shrub fuel characteristics were classified based on the tasseled cap transformation of Landsat TM multispectral data (Cohen, 1989). van Wagtendonk and Root (2003) implemented an unsupervised classification algorithm to define 30 unique spectral-temporal classes of Normalised Difference Vegetation Index (NDVI) values. Later, a combination of graphical, statistical and visual techniques allowed the characterization of the 30 classes and identified those that responded similarly and could be combined into fuel models for Yosemite National Park, USA. The accuracy reported by these authors is $65 \%$. The combined use of Landsat data with ancillary data (i.e. NDVI, slope, texture, illumination) improved the accuracy of discriminating some fuel types up to $85.9 \%$ (Riano et al., 2002; Francesetti et al., 2006). These results reveal the convenience of integrating different sources of information for fuel mapping.

Other efforts have concentrated on coarse spatial resolution sensors, such as NOAA-AVHRR (National Oceanographic and Atmospheric Administration-Advanced Very High Resolution Radiometer) images (McGinnis and Tarpley, 1985; Maselli et al., 2003). The main advantage of this sensor is the possibility of updating the information on a daily basis. However, the low spatial resolution of the sensor (close to $1 \mathrm{~km}$ at nadir) limits its utility to regional and global scales.

More recently, advanced spaceborne thermal emission and reflection radiometer (ASTER) imagery has proved useful for the characterization and mapping of fuel types and fire risk at finer scales, showing overall accuracies of more than $90 \%$ (Guang-xiong et al., 2007; Lasaponara and Lanorte, 2007b).

\subsubsection{Very high resolution multispectral data}

Newer sensors, such as QuickBird and IKONOS, have eventually provided sub-meter spatial resolutions. These sensors have been widely applied in vegetation characterization (Wang et al., 2004; Hyde et al., 2006; Kayitakire et al., 2006; van Coillie et al., 2007; Mallinis et al., 2008) and they may well become a valuable input for the development of local fuel management plans, particularly for the urban-wildland interface, where the risk to life and property is acute (Andrews and Queen, 2001). However, fire researchers have not paid adequate attention to the potential benefits of using VHR satellite data to map fuel types and properties (Lasaponara and Lanorte, 2007a) and very few works have focused on this source of information for forest fuel characterization.

When this imagery became available, several authors reported a singular behaviour (Blaschke and Strobl, 2001; Sawaya et al., 2003; van der Sande et al., 2003). The high spatial resolution increases the spectral within-field variability, in contrast to the integration effect of earlier sensors, and the traditional pixel-based methods were hampered by this higher variability (Puissant et al., 2005). To overcome this limitation, an object-oriented approach can be used. In this approach, pixels are aggregated before classification, not after. It creates regions as carriers of features, such as form, texture, context, and spectral information that are then introduced in the classification stage. Classification is then performed on groups of pixels ("objects"), rather than on single pixels. Hence, the feature space can be extended to spectral as well as non-spectral features, which contributes to improved distinction between defined object classes.

In the Mediterranean basin, Giakoumakis et al. (2002) and Gitas et al. (2006) employed this technique to map the Prometheus fuels types using IKONOS and QuickBird imagery, respectively. Their overall accuracy reached up to $75 \%$. Similar precision was reported by Lasaponara and Lanorte (2007a) when they applied a maximum likelihood algorithm over VHR QuickBird image in the South of Italy. Arroyo et al. (2006) implemented an object-oriented approach to map forest fuels in central Spain. These authors developed a multi-scale segmentation approach with a hierarchical three-level network of image objects. Objects were classified using a nearest neighbour classifier and context information (objects of one level informed the classification of other-level objects). They reported an overall accuracy of $81.5 \%$. Finally, similar precision was reported by Lasaponara and Lanorte (2007b) when they applied a maximum likelihood algorithm over VHR QuickBird image in the South of Italy.

Even though very few papers have been published in relation to VHR imagery and fuel mapping, the levels of accuracy attained thus far are comparable to those reported for medium-resolution sensors (Table 6). This fact reveals the potential of using VHR imagery for forest fuel mapping, an option that has not been explored in depth yet. Promising results were also obtained when VHR data were combined with LiDAR information (Mutlu et al.,

Table 7

Characteristics of some hyperspectral sensors commonly used in forest fuel mapping

\begin{tabular}{|c|c|c|c|c|c|c|c|}
\hline Sensor & Platform & $\begin{array}{l}\text { Spatial } \\
\text { resolution (m) }\end{array}$ & $\begin{array}{l}\text { Spectral } \\
\text { resolution }(\mathrm{nm})\end{array}$ & No. of bands, wavelengths & Estimated parameters & Accuracy & Reference \\
\hline MIVIS & Airborne & 4 & $20-50$ & 102 bands $(433-12,700 \mathrm{~nm})$ & Vegetation typology & 0.9 & Lasaponara and Lanorte (2006) \\
\hline \multirow[t]{2}{*}{ AVIRIS } & Airborne & $4-20$ & 10 & 224 bands $(370-2510 \mathrm{~nm})$ & Foliar biochemistry & $0.4-0.77$ & $\begin{array}{l}\text { Jia et al. (2006a) and Roberts } \\
\text { etal. (1998) }\end{array}$ \\
\hline & & & & & Fuel moisture & 0.79 & \\
\hline DAIS7915 & Airborne & 5 & 40 & 79 bands $(500-13,000 \mathrm{~nm})$ & LAI; \% vegetation cover & $0.72-0.78$ & Kotz et al. (2004) \\
\hline Hyperion & EO1 Satellite & 30 & 10 & 242 bands $(357-2576 \mathrm{~nm})$ & $\begin{array}{l}\text { Vegetation type; } \\
\text { vegetation density }\end{array}$ & 0.93 & Keramitsoglou et al. (2008) \\
\hline
\end{tabular}


2008), indicating that the integration of different sensors may further improve fuel discrimination.

\subsubsection{Hyperspectral data}

Hyperspectral remote sensing systems, which measure reflected or emitted electromagnetic radiation over a large number of contiguous spectral bands, have been shown to be useful for the spectral and spatial discrimination of fire-related vegetation attributes such as green canopy closure, vegetation moisture, ratio dead to live plant materials and distribution of bare ground (Roberts et al., 2003; Ustin et al., 2004; Jia et al., 2006a). Spectral Mixture Analysis (SMA) is the base of most hyperspectral data analysis techniques. The SMA approach assumes that the spectrum measured by a sensor is a linear combination of the spectra of all components within the pixel, called endmembers (Adams et al., 1995; Roberts et al., 1998). Generally, reference endmembers are acquired by field or laboratory measurements with portable spectrometers or derived from spectral libraries. The main characteristics of the hyperspectral sensors applied in these studies are presented in Table 7.

Roberts et al. (1997) pioneered the spectral characterization of fuel condition (relative proportion of live to dead or senescent fuel) using a temporal sequence of airborne visible/infrared imaging spectrometer (AVIRIS) imagery (with 224 bands). AVIRIS data were also used for mapping chaparral fuels in California, implementing multiple-endmember-spectral mixture analysis (MESMA), an alternative to the SMA technique that allows types and number of endmembers to vary on a per pixel basis (Roberts et al., 1998). More recently, Jia et al. (2006a) implemented several SMA techniques with AVIRIS data for mapping three major forest components (photosynthetic vegetation (PV), non-photosynthetic vegetation (NPV) and bare soil) and fuel types in montane coniferous forests in the Colorado Front Range (USA). In addition, Jia et al. (2006b) combined field spectroscopy and airborne hyperspectral AVIRIS data to discriminate forest cover of two conifers, ponderosa pine (Pinus ponderosa) and Douglas-fir (Pseudotsuga menziesii), a distinction which allows the prediction of fire spread in the Rocky Mountains (Colorado, USA). AVIRIS data have also been employed for other fire-related applications, such as mapping fire temperature and land cover in wildland fires (Dennison et al., 2006). Other airborne hyperspectral sensor (Digital Airborne Imaging Spectrometer: DAIS7915, see Table 7) data have been processed to estimate fuel parameters and foliage water content of coniferous canopy in the Alps (Kotz et al., 2004). The highest accuracy levels (90\%) have been obtained from MIVIS (Multispectral Infrared Visible Imaging Spectrometer) (Lasaponara and Lanorte, 2006). Other alternatives, such as the use of AVIRIS-derived canopy water content for fuel mapping, have not been directly used, but they could be applied (Cheng et al., 2006).

The main disadvantage of the airborne hyperspectral sensors (e.g. AVIRIS, MIVIS) is the reduced spatial coverage that they provide. In this sense, satellite-based hyperspectral sensors offer a more promising alternative, allowing more consistent and economic monitoring than the airborne sensors (Table 7). This is the case of Hyperion, which has been successfully used to map forest types and densities for fuel models mapping and fire risk assessment. Keramitsoglou et al. (2008) reported an overall accuracy up to $93 \%$ and $84 \%$ for Hyperion and ASTER data, respectively. On the other hand, comparison between two fuel maps derived from AVIRIS and Hyperion imagery revealed a similar distribution pattern for both hyperspectral sensors, but better precision was obtained for AVIRIS (overall accuracies of 79\% versus 50\%) (Roberts et al., 2003).

\subsection{Active sensors}

\subsubsection{LiDAR systems}

LiDAR technology is becoming an effective alternative for overcoming the two main difficulties encountered when mapping fuels from passive optical data: it can be used to estimate fuel heights, which is critical both in fuel loads assessment and fuel types discrimination; and it provides information of surface fuels when they are covered by the forest canopy (Keane et al., 2001; Chuvieco and Kasischke, 2007). LiDAR data have also been used for obtaining other parameters used in fire behaviour modelling, such as canopy based height and crown bulk density.

Some fuel characteristics can be directly derived from the LiDAR data (Dubayah and Drake, 2000). Canopy height, used to define several fuel types, can be estimated from small footprint LiDAR systems (see Lefsky et al., 2002; Chuvieco et al., 2003 for system description) after filtering the raw data to separate ground and canopy hits (Suarez et al., 2005; Hyyppa et al., 2008). A digital canopy model (DCM) can be retrieved by interpolating and subtracting a digital terrain model (DTM) (obtained from the ground hits) from a digital surface model (DSM) (obtained from the canopy hits). The percentage tree cover, also employed in several fuel type classifications, is usually obtained by dividing the sums of canopy and ground reflections. The sum of canopy reflections is the sum of the pulses classified as vegetation and the sum of ground reflections is the sum of pulses classified as ground multiplied by a correction factor for the canopy attenuation. Generally the greater the canopy cover is, the lower the laser pulse can penetrate through the canopy (Chuvieco et al., 2003; Hyyppa et al., 2008). Other critical variables to model fire behaviour have also been accurately derived using small footprint LiDAR data. Riano et al. (2003, 2004) estimated surface canopy height, surface canopy cover, canopy base height and crown bulk density from airborne laser scanner (ALS) data in forests dominated by conifer and deciduous tree species. Andersen et al. (2005) and Hall et al. (2005) used this sensor to estimate canopy base height and canopy bulk density. These authors carried out a regression analysis relating different LiDAR-based metrics to field-measured fuel parameters. Morsdorf et al. (2004) also employed ALS data to measure individual tree crown dimensions for forest fire risk assessment in Switzerland. Finally, Skowronski et al. (2007) used LiDAR measurements of canopy height to quantify forest structure and ladder fuels (defined as vertical fuel continuity between the understory and canopy).

There are also several published studies whose main objectives were not directly related to forest fuel characterization, but nonetheless give results that suggest that LiDAR data may well be employed in this direction. Some of them have focused on the identification (or segmentation) of individual tree crowns for geometric feature extraction. Holmgren and Persson (2004) extracted tree heights and several crown dimensions after isolating individual trees. Their aim was to identify different hardwood species. Suarez et al. (2005) used a similar approach in order to estimate individual tree heights. Other studies dealing with the use of LiDAR data to analyse forest structure, a very active research area, can also be of applied to forest fuel characterization. For example, coarse woody debris volume has been predicted by relating field plot measurement and ALS derived metrics (Pesonen et al., 2008). Popescu and Zhao (2008) developed a technique to characterize vertical structure of individual tree crowns and to estimate crown base height for each tree identifiable on the DCM. Among these studies, field observed versus predicted values were highly correlated, with $\mathrm{r}^{2}$ ranging from 0.60 to 0.80 . A huge body of evidence is growing supporting the use of LiDAR data to 
characterize forest canopy and subcanopy forest, both in the horizontal and vertical planes (Hyyppa et al., 2008).

\subsubsection{Microwave data}

As in the case of LiDAR data, microwave sensors have the potential to complement optically measured characteristics of fuel types. According to Chuvieco et al. (2003), several projects based on satellite microware data from ERS-1 (European Remote Sensing satellite - 1; which includes an imaging Synthetic Aperture Radar (SAR)), JERS-1 (Japanese Earth Resources Satellite -1) and RADARSAT (developed by Canada) data have been undertaken to predict forest attributes that are critical for fuel type mapping, such as foliar biomass, tree volume, tree height and canopy closure (Harrell et al., 1995; Ranson et al., 1997; Hyyppa et al., 2000; Toutin and Amaral, 2000; Austin et al., 2003; Neeff et al., 2003; Li et al., 2007; Smith-Jonforsen et al., 2007; Garestier et al., 2008; Kononov and Ka, 2008). Even though these studies have generated positive results and expectations, very few papers describe the use of satellite radar data to specifically estimate fuel loads or map fuel types. Saatchi et al. (2007) developed semi-empirical algorithms over SAR imagery to estimate the distribution of biomass and three major fuel load parameters (i.e. canopy fuel weight, canopy bulk density and foliage moisture content) of the Yellowstone National Park. Their approach provided levels of accuracy ranging from $70 \%$ to $85 \%$. Current limitations of satellite microwave data preclude their use for accurate estimation of canopy height, since the uncertainty in the estimation is greater than $5 \mathrm{~m}$ (Hyyppa et al., 2000; Toutin and Amaral, 2000). Additionally, only long-wave radar systems (L and P) are able to penetrate the forest canopy, and only a few systems (JERS, Shuttle Imaging Radar (SIR)) have used L band. Another limitation is that satellite radar is insensitive to high biomass levels (Kasischke et al., 1997).

Airborne profiling radar has provided accurate estimates of canopy height of up to 1-1.5 m (Hyyppa and Hallikainen, 1993, 1996; Hyyppa et al., 2008), which is still not sufficient for obtaining a direct estimation of some fuel types. Several BEHAVE shrub fuel types, for example, are defined according to height intervals of $0.6 \mathrm{~m}$. Another limitation is that the technique is not capable of providing three-dimensional information about vegetation structure. In addition, the radar does not operate on steep slopes (Castel et al., 2000).

In any case, microware data could be an ideal complement to LiDAR measurements, since it is cheaper to acquire and therefore allows larger areas to be analysed (Slatton et al., 2001). Radar could thus be applied to interpolate between LiDAR footprints or even to extrapolate where no LiDAR measurements are taken. Radar data could also be useful for analysing temporal variability of fuels, one of the main challenges reported by Keane et al. (2001). In fact, the latest research trends related to forest fire and microwave data focus on fuel moisture estimation for fire danger prediction (Bourgeau-Chavez et al., 2000, 2007; Abbott et al., 2002, 2007).

\section{Combined methods to map fuel types}

The combined use of more than one fuel mapping method and/ or data sources represents a new and promising approach in remote sensing, not only for fuel mapping but also in many other applications. In fact, most of the latest studies of forest fuels integrate more than one source of information. As a result, many of the limitations associated with the application of a single mapping method have been addressed. In contrast to previous sections, which presented the advances of different remote sensing techniques and products when they are employed alone, we will now focus on the combination of different mapping methods in an integrated approach.
One option is to combine traditional and remote sensing techniques. At the beginning of this decade, Keane et al. (2000, 2001) already proposed an integrated approach that merged extensive field sampling, image classification of vegetation characteristics and biophysical gradient modelling. A few years later, Falkowski et al. (2005) implemented a different integrated method by combining digital analysis of ASTER imagery with gradient modelling methods for mapping fuel layers for fire behaviour modelling with FARSITE. More recently, Poulos et al. (2007) used field data, remotely sensed data and landscape metrics derived from digital elevation models to develop predictive vegetation and fuel maps in Texas. They developed a hierarchical approach for scaling fuel maps from local to landscape scales.

Using only remote sensing techniques, the integration of more than one sensor has also been successfully developed. The integration of LiDAR and spectral information (mainly VHR or hyperspectral) has been particularly successful and represents a promising alternative to deal with the complex nature of fuels. Riano et al. (2007) used infrared orthophotos and LiDAR data to estimate shrub height for fuel mapping. They employed NDVI values derived from the optical data to enhance the LiDAR derived DTM. Varga and Asner (2008) modelled fuel load across a gradient of ecosystems (from forest to savannah to shrubland) by combining LiDAR and hyperspectral data. An automated SMA of AVIRIS imagery provided fractional cover estimates of PV, NPV and bare soil or shade and small footprint LiDAR provided measurements of vegetation heights. The authors used that information to develop a new fire fuel index, estimated as the ratio between percentage of NPV cover and the maximum canopy height for each pixel. These authors paired the remote sensing approach with a method for rapid (near real-time) assessment of fire fuel condition at large scale. More recently, Mutlu et al. (2008) investigated the gain in fuel mapping accuracy when incorporating LiDAR data, as opposed to QuickBird imagery alone. Their results showed that combining both imageries improved the overall accuracy of the fuel classification. The best results gave an accuracy assessment of $90 \%$, which increased the overall accuracy by $14 \%$, as compared to the QuickBird image alone.

\section{Conclusions}

The knowledge of fuel characteristics is essential to fire and land management because it can be used to compute fire hazard, risk, behaviour and effects. However, fuels are difficult to describe and map due to their high complexity and variability.

With the development of different fire models, several fuel classification systems have been created around the world. Each fuel classification only considers those fuels characteristics required by the fire model for which it was developed and is therefore specific to it. Moreover, these fire models and fuel classifications are normally only applicable for the purpose they were developed and the location where they were created. Thus, the selection of an appropriate classification system is essential when mapping forest fuels. Different classification systems must be applied depending on what needs to be predicted, where and how.

Forest fuel mapping has traditionally been performed by means of field work, the use of aerial photography and ecological modelling. Such methodologies suffer from several limitations. They require abundant field work, which is time-consuming and expensive. Nevertheless, they still play an important role and represent a useful complement to the remote sensing approaches. They provide the field reference datasets necessary to validate maps created from remotely sensed data products. More than that, 
in some cases their incorporation to other techniques has remarkably improved the results obtained before their addition.

In remote sensing, it is possible to use a large variety of systems. Different sensors, methods of image capture and platforms will be used depending on the purpose for which they will be employed. In general, remote sensing methods offer several advantages. They can offer cost-effective ways to assess wildfire risks in nearly realtime with wider spatial and regular temporal coverage. Also, data are processed digitally, making possible analyses that are complex, expensive or impossible with visual products.

Several shortcomings have traditionally limited the use of remote sensed data for fuel mapping. Optical satellite data and aerial photography are limited to observing the horizontal fuel distribution and are constrained by their inability to reveal understory characteristics or to estimate heights. Although some studies have increased the levels of accuracy of these products, these limitations have not been overcome and some fuel characteristics must be obtained through other means, such as by the use of active sensors.

The development of new improved sensors (i.e. LiDAR, radar, VHR and hyperspectral) and techniques (i.e. able to handle heterogeneous data sources, object-oriented image analysis and context information) may considerably improve fuel mapping tasks. Future research should focus on the integration of mapping techniques and sensor data. The use of object-oriented image analysis is particularly promising, given its ability to integrate and process data with very different properties. This approach has been successfully employed for vegetation mapping and could also be applied to map fuel types.

\section{Acknowledgments}

Funding by the Fundacion Alonso Martin Escudero (Spain) is gratefully acknowledged. Further support was provided by the Centre for Remote Sensing and Spatial Information, at University of Queensland, Australia. This paper was improved by comments from two anonymous reviewers. We thank S. Iglesias for his help with the editing of this manuscript.

\section{References}

Abbott, K., Leblon, B., Staples, G., Alexander, M.E., MacLean, D., 2002. Use of RADARSAT-1 images to map forest fuel moisture over boreal forests. In: Igarss 2002: Ieee International Geoscience and Remote Sensing Symposium and 24th Canadian Symposium on Remote Sensing, Vols. I-Vi, Proceedings, pp. 134-136.

Abbott, K.N., Leblon, B., Staples, G.C., Maclean, D.A., Alexander, M.E., 2007. Fire danger monitoring using RADARSAT-1 over northern boreal forests. International Journal of Remote Sensing 28, 1317-1338.

Adams, J.B., Sabol, D.E., Kapos, V., Filho, R.A., Roberts, D.A., Smith, M.O., Gillespie, A.R., 1995. Classification of multispectral images based on fractions of endmembers: Application to land cover change in the Brazilian Amazon. Remote Sensing of Environment 52, 137-154.

Adams, J.L, 1965. Fuel Classification and Mapping for Forest Fire Control. University of California, Berkeley.

Albini, F.A., 1976. Estimating wildfire behavior and effects. Rep. No. GTR INT-30. USDA, Forest Service, Intermountain Forest and Range Experiment Station, Ogden, UT.

Alloza, J.A., Baeza, M.J., Riva, J.D.I., Duguy, B., Echeverria, M.T., Ibarra, P., Llovet, J., Perez-Cabello, F., Rovira, P., Vallejo, V.R., 2006. A model to evaluate the ecological vulnerability to forest fires in Mediterranean ecosystems. Forest Ecology and Management 234, S203.

Andersen, H.-E., McGaughey, R.J., Reutebuch, S.E., 2005. Estimating forest canopy fuel parameters using LIDAR data. Remote Sensing of Environment 94,441-449.

Anderson, H.E., 1982. Aids to determining fuel models for estimating fire behavior. Rep. No. GTR INT-122. USDA, Forest Service, Ogden, UT.

Andrews, P.L., 1986. BEHAVE: Fire behavior prediction and fuel modeling system. Burn subsystem. Part 1. Rep. No. GTR INT-194. USDA Forest Service, Intermountain Forest and Range Experiment Station, Ogden, UT.

Andrews, P.L., Queen, L.P., 2001. Fire modeling and information system technology. International Journal of Wildland Fire 10, 343-352.

Arroyo, LA, Healey, S.P., Cohen, W.B., Cocero, D., 2006. Using object-oriented classification and high-resolution imagery to map fuel types in a Mediterranean region. Journal of Geophysical Research 111, G04S04 doi:10.1029/ 2005JG000120.

Arroyo, L.A., Cocero, D., Manzanera, J.A., Garcia-Montero, LG., Pascual, C, 2005. El empleo de clasificadores de contexto para la obtencion de cartografia en la interfase urbano forestal. GeoFocus 5, 115-128.

Austin, J.M., Mackey, B.C., Van Niel, K.P., 2003. Estimating forest biomass using satellite radar: an exploratory study in a temperate Australian Eucalyptus forest. Forest Ecology and Management 176, 575-583.

Barrett, S.W., 1988. Suppression's effects on forest succession within a central Idaho wilderness. Western Journal of Applied Forestry 3, 76-80.

Bertolette, D.R., Spotskey, D.B., 1999. Fuel model and forest type mapping for FARSITE. In: The Joint Fire Science Conference and Workshop. University of Idaho and International Association of Wildland Fire, Boise, Idaho.

Blaschke, T., Strobl, J., 2001. What's wrong with pixels? Some recent developments interfacing remote sensing and CIS. CIS - Zeitschrift fur Geoinformationssysteme $6,12-17$.

Bourgeau-Chavez, L.L., Kasischke, E.S., Rutherford, M.D., 2000. Evaluation of ERS SAR data for prediction of fire danger in a boreal region. International Journal of Wildland Fire 9, 183-194.

Bourgeau-Chavez, L.L., Garwood, G., Riordan, K, Cella, B., Alden, S., Kwart, M. Murphy, K., 2007. Improving the prediction of wildfire potential in boreal Alaska with satellite imaging radar. Polar Record 43, 321-330.

Brown, J.K., Oberheu, R.D., Johnson, CM., 1982. Handbook for inventorying surface fuels and biomass in the interior west. Rep. No. GTR INT-129. USDA Forest Service, Intermountain Forest and Range Experiment Station, Odgen, UT.

Burgan, R., Rothermel, R.C., 1984. BEHAVE: Fire Behaviour Prediction and Fuel Modeling System-FUEL Subsystem. Rep. No. GTR INT-167. Intermountain Forest and Range Experiment Station, Ogden, UT.

Burgan, R., Klaver, R., Klaver, J., 1998. Fuel model and fire potential from satellite and surface observations. International Journal of Wildland Fire 8, 159-170.

Castel, T., Martinez, J.M., Beaudoin, A., Wegmuller, U., Strozzi, T., 2000. ERS INSAR data for remote sensing hilly forested areas. Remote Sensing of Environment 73, 73-86.

Castro, R., Chuvieco, E., 1998. Modeling forest fire danger from geographic information systems. Geocarto International 13, 15-23.

Cheney, N.P., Gould, J.S., 1996. Development of fire behaviour models for highintensity forest fires. In: Conference of Natural Disaster Reduction, Gold Coast, Australia, pp. 165-170.

Cheng, Y.B., Zarco-Tejada, P.J., Riano, D., Rueda, C.A., Ustin, S.L, 2006. Estimating vegetation water content with hyperspectral data for different canopy scenarios: Relationships between AVIRIS and MODIS indexes. Remote Sensing of Environment 105, 354-366.

Chuvieco, E., Congalton, R.G., 1989. Application of remote sensing and geographic information systems to forest fire hazard mapping. Remote Sensing of Environment 29, 147-159.

Chuvieco, E., Salas, J., 1996. Mapping the spatial distribution of forest fire danger using CIS. International Journal of Geographical Information Science 10 333-345.

Chuvieco, E., Kasischke, E.S., 2007. Remote sensing information for fire management and fire effects assessment. Journal of Geophysical Research-Biogeosciences 112 .

Chuvieco, E., Carvacho, L., Rodriguez-Silva, F., 1999. Integrated fire risk mapping. In: Chuvieco, E. (Ed.), Remote Sensing of Large Wildfires. Springer, Berlin, pp. 61-84.

Chuvieco, E., Riano, D., van Wagtendonk, J., Morsdof, F., 2003. Fuel loads and fuel type mapping. In: Chuvieco, E. (Ed.), Wildland Fire Danger Estimation and Mapping. The Role of Remote Sensing Data. World Scientific, Singapore, pp. 119-142.

Chuvieco, E., Cocero, D., Riano, D., Martin, P., Martinez-Vega, J., Riva, J.d.L, Perez, F., 2004. Combining NDVI and surface temperature for the estimation of live fuel moisture content in forest fire danger rating. Remote Sensing of Environment 92, 322-331.

Cohen, J.D., Deeming, J.E., 1982. The National Fire Danger Rating System: basic equations. Rep. No. PSW-82. Pacific Southwest Forest and Range Experiment Station, Berkeley, CA.

Cohen, W.B., 1989. Potential utility of the TM tasseled cap multispectral data transformation for crown fire hazard assessment. In: ASPRS/ACSM annual convention proceedings: Agenda for the 90s', vol. 3, Baltimore, MD, pp. 118-127.

De Wulf, R.R., Goossens, R.E., Deroover, B.P., Borry, F.C., 1990. Extraction of forest stand parameters from panchromatic and multispectral SPOT-1 data. International Journal of Remote Sensing 11, 1571-1588

Deeming, J.E., Burgan, RE., Cohen, J.D., 1977. The National Fire Danger Rating System. Rep. No. GTR INT-39. USDA Forest Service, Intermountain Forest and Range Experiment Station, Ogden, UT.

Deeming, J.E., Lancaster, J.W., Fosberg, M.A., Furman, R.W., Schroeder, M.J., 1972. The National Fire-Danger Rating System. Rep. No. RM-84. USDA Forest Service, Ogden, UT.

Dennison, P.E., Charoensiri, K., Roberts, DA, Peterson, S.H., Green, R.O., 2006. Wildfire temperature and land cover modeling using hyperspectral data. Remote Sensing of Environment 100, 212-222.

Dubayah, R.O., Drake, J.B., 2000. Lidar remote sensing of forestry. Journal of Forestry $98,44-46$.

Falkowski, M.J., Gessler, P.E., Morgan, P., Hudak, A.T., Smith, A.M.S., 2005. Characterizing and mapping forest fire fuels using ASTER imagery and gradient modeling. Forest Ecology and Management 217, 129-146. 
Fernandes, P., Luz, A., Loureiro, C, Ferreira-Godinho, P., Botelho, H., 2006. Fuel modelling and fire hazard assessment based on data from the Portuguese National Forest Inventory. Forest Ecology and Management 234S

Fernandez, C, Vega, J.A., Fonturbel, T., Perez-Gorostiaga, P., Jimenez, E., Madrigal, J., 2007. Effects of wildfire, salvage logging and slash treatments on soil degradation. Land Degradation \& Development 18, 591-607.

Finney, M.A., 1998. FARSITE: fire area simulator-model development and valuation. Rep. No. Paper RMRS-RP-4. USDA Forest Service, Ogden, UT.

Finney, M.A., 2004. FARSITE: fire area simulator-model development and valuation (revised). Rep. No. Paper RMRS-RP-4 revised. Rocky Mountain Research Station, Ogden, UT.

Fogarty, L.G., Pearce, G., Catchpole, W.R., Alexander, M.E., 1998. Adoption versus adoption: lessons learned from applying the Canadian Forest Fire Danger Rating System to New Zeeland. In: Viegas (Eds.), Proceedings 3rd International Conference Forest Fire Research, Luso, Coimbra, Portugal, pp. 1011-1028.

Forestry Canada, 1992. Development and structure of the Canadian Forest Fire Behavior Prediction System. Rep. No. ST-X-3. Forestry Canada, Ottawa.

Francesetti, A., Camia, A., Bovio, G., 2006. Fuel type mapping with Landsat TM images and ancillary data in the Prealpine region of Italy. Forest Ecology and Management 234S, S259.

Fryer, G.I., Johnson, E.A., 1988. Reconstructing fire behaviour and effects in a subalpine forest. The Journal of Applied Ecology 25, 1063-1072.

Garestier, F., Dubois-Fernandez, P.C., Papathanassiou, K.P., 2008. Pine forest heigh inversion using single-pass $\mathrm{X}$-band PolInSAR data. IEEE Transactions on Geoscience and Remote Sensing 46, 59-68.

Giakoumakis, N.M., Gitas, I.Z., San-Miguel, J., 2002. Object-oriented classification modelling for fuel type mapping in the Mediterranean, using LANDSAT TM and IKONOS imagery_preliminary results. In: Viegas (Eds.), Forest Fires Research \& Wildland Fire Safety. Millpress, Rotterdam.

Gitas, I.Z., Mitri, G.H., Kazakis, G., Ghosn, D., Xanthopoulos, G., 2006. Fuel type mapping in Annapolis, Crete by employing QuickBird imagery and object-based classification. Forest Ecology and Management 234 (SI), S228 doi:10.1016/ j.foreco. 2005.08.255

Guang-xiong, P., Jing, L., Yun-hao, C, Abdul-patah, N., 2007. A forest fire risk assessment using ASTER images in peninsular Malaysia. Journal of China University of Mining \& Technology 17, 232-237.

Hall, S.A., Burke, 1.C, 2006. Consideration for characterizing fuels as inputs for fire behavior models. Forest Ecology and Management 227, 102-114.

Hall, S.A., Burke, 1.C, Box, D.O., Kaufmann, M.R., Stoker, J.M., 2005. Estimating stand structure using discrete-return lidar: an example from low density, fire prone ponderosa pine forests. Forest Ecology and Management 208, 189-209.

Hardy, C.C., Hardy, C.E., 2007. Fire danger rating in the United States of America: an evolution since 1916. International Journal of Wildland Fire 16, 217-231

Harrell, P., Bourgeau-Chavez, LL., Kasischke, E.S., French, N.H.F., Christensen, N.L.J., 1995. Sensitivity of ERS-1 andJERS-1 radar data to biomass and stand structure in Alaskan boreal forest. Remote Sensing of Environment 54, 247-260.

Harvey, S., Riiegsegger, M., Allgower, B., 1997. Fuel Models for Switzerland (Swiss National Park). Rep. No. BBW Nr. 94.0177, EC Nr. EV5VCT-0570. Department of Geography, Zurich

Holmgren, J., Persson, A., 2004. Identifying species of individual trees using airborne laser scanner. Remote Sensing of Environment 90, 415-423.

Hornby, L.G., 1935. Fuel type mapping in region one. Journal of Forestry 33,67-72.

Hyde, P., Dubayah, R., Walker, W., Blair, J.B., Hofton, M., Hunsaker, C, 2006. Mapping forest structure for wildlife habitat analysis using multi-sensor (LiDAR, SAR/ InSAR, ETM+, Quickbird) synergy. Remote Sensing of Environment 102, 63-73.

Hyyppa, H., Hallikainen, M., 1993. A helicopter-borne 8-channel ranging scatte rometer for remote-sensing 2. Forest inventory. IEEE Transactions on Geoscience and Remote Sensing 31, 170-179.

Hyyppa, H., Hallikainen, M., 1996. Applicability of airborne profiling radar to forest inventory. Remote Sensing of Environment 57, 39-57.

Hyyppa, J., Hyyppa, H., Inkinen, M., Engdahl, M., Linko, S., Zhu, Y.H., 2000. Accuracy comparison of various remote sensing data sources in the retrieval of forest stand attributes. Forest Ecology and Management 128, 109-120.

Hyyppa, J., Hyyppa, H., Leckie, D., Gougeon, F., Yu, X., Maltamo, M., 2008. Review of methods of small-footprint airborne laser scanning for extracting forest inventory data in boreal forests. International Journal of Remote Sensing 29, 13391366

James, P.M.A., Fortin, M.-J., Fall, A., Kneeshaw, D., Messier, C, 2007. The effects of spatial legacies following shifting management practices and fire on borea forest age structure. Ecosystems 10, 1261-1277 doi: 10.1007/s 10021-0079095-y.

Jia, G.J., Burke, 1.C, Goetz, A.F.H., Kaufmann, M.R., Kindel, B.C., 2006a. Assessing spatial patterns of forest fuel using AVIRIS data. Remote Sensing of Environment $102,318-327$

Jia, G.J., Burke, 1.C, Kaufmann, M.R., Goetz, A.F.H., Kindel, B.C., Pu, Y., 2006b Estimates of forest canopy fuel attributes using hyperspectral data. Forest Ecology and Management 229, 27-38.

Kasischke, E.S., Melack, J.M., Dobson, M.C, 1997. The use of imaging radars for ecological applications-a review. Remote Sensing of Environment 59,141-156.

Kayitakire, F., Hamel, C, Defourny, P., 2006. Retrieving forest structure variables based on image texture analysis and IKONOS-2 imagery. Remote Sensing of Environment 102, 390-401.

Keane, RE., Burgan, R.E., van Wagtendonk, J., 2001. Mapping wildland fuel for fire management across multiple scales: Integrating remote sensing, CIS, and biophysical modeling. International Journal of Wildland Fire 10, 301-319.
Keane, R.E., Long, D.G., Schmidt, K.M., Mincemoyer, S., Garner, J.L., 1998. Mapping fuels for spatial fire simulations using remote sensing and gradient biophysical modelling. In: 7th Forest Service remote sensing applications conference, American Society of Photogrammetry and Remote Sensing, Bethesda, MD.

Keane, R.E., Mincemoyer, S.S., Schmidt, KM., Long, D.G., Garner, J.L., 2000. Mapping vegetation and fuels for fire management on the Gila National Forest Complex, New Mexico. Rep. No. RMRS-GTR-46-cd. US Department of Agriculture, Forest Service, Rocky Mountain Research Station.

Keramitsoglou, I., Kontoes, C, Sykioti, O., Sifakis, N., Xofis, P., 2008. Reliable, accurate and timely forest mapping for wildfire management using ASTER and Hyperion satellite imagery. Forest Ecology and Management 255, 3556-3562.

Kitchen, K., Marno, P., Legg, C, Bruce, M., Davies, G.M., 2006. Developing a fire danger rating system for the United Kingdom. Forest Ecology and Management 234S, S21.

Kononov, A.A., Ka, M.H., 2008. Model-associated forest parameter retrieval using VHFSAR data at the individual tree level. IEEE Transactions on Geoscience and Remote Sensing 46, 69-84.

Kotz, B., Schaepman, M., Morsdorf, F., Bowyer, P., Itten, K., Allgower, B., 2004. Radiative transfer modeling within a heterogeneous canopy for estimation of forest fire fuel properties. Remote Sensing of Environment 92, 332-344.

Kourtz, P.H., 1977. An application of Landsat digital technology to forest fire fuel type mapping. In: 11 th International Symposium on Remote Sensing of Environment, Ann Arbor, pp. 1111-1115.

Lasaponara, R., Lanorte, A., 2006. Multispectral fuel type characterization based on remote sensing data and Prometheus model. Forest Ecology and Management 234S, S226.

Lasaponara, R. Lanorte, A., 2007a. On the capability of satellite VHR QuickBird data for fuel type characterization in fragmented landscape. Ecological Modelling 204, 79-84

Lasaponara, R., Lanorte, A., 2007b. Remotely sensed characterization of forest fuel types by using satellite ASTER data. International Journal of Applied Earth Observation and Geoinformation 9, 225-234.

Lawson, B.D., Stocks, B.J., Alexander, M.E., van Wagner, C.E., 1985. A system for predicting fire behaviour in Canadian forest. In: Eighth Conference on Fire and Forest Meteorology. Society of American Foresters, Detroit.

Lee, H.C, 1941. Aerial photography: a method for fuel type mapping. Journal of Forestry 39, 531-533

Lefsky, M.A., Cohen, W.B., Parker, G.G., Harding, D.J., 2002. Lidar Remote Sensing for Ecosystem Studies. BioScience 52.

Li, X., Yeh, A.G.O., Wang, S., Liu, K., Liu, X., Qian, J., Chen, X., 2007. Regression and analytical models for estimating mangrove wetland biomass in South China using Radarsat images. International Journal of Remote Sensing 28,5567-5582.

Lund, H.G., 1969. Appraising and mapping fuels with aerial photographs. Rep. No. Proceedings American Society of Photogrammetry and American Congress on Surveying and Mapping. American Society of Photogrammetry, Portland, OR.

Lundgren, S., Mitchell, W., Wallace, M., 1995. A status report on NFMAS-an interagency system update project. Fire Management Notes 55, 11-12.

Mallinis, G., Koutsias, N., Tsakiri-Strati, M., Karteris, M., 2008. Object-based classification using Quickbird imagery for delineating forest vegetation polygons in a Mediterranean test site. ISPRS Journal of Photogrammetry and Remote Sensing $63,237-250$.

Marsden-Smedley, J.B., Catchpole, W.R., 1995a. Fire behaviour modelling in Tasmanian buttongrass moorlands. II Fire behaviour. International Journal of Wildland Fire 5, 215-228.

Marsden-Smedley, J.B., Catchpole, W.R., 1995b. Fire behaviour modelling in Tasmanian buttongrass moorlands I. Fuel characteristics. International Journal of Wildland Fire 5, 203-214

Marsden-Smedley, J.B., Catchpole, W.R., 2001. Fire behaviour modelling in Tasmanian buttongrass moorlands. Ill Dead fuel moisture. International Journal of Wildland Fire 10, 241-253.

Marsden-Smedley, J.B., Catchpole, W.R., Pyrke, A., 2001. Fire behaviour modelling in Tasmanian buttongrass moorlands. IV Sustaining versus non-sustaining fires. International Journal of Wildland Fire 10, 255-262.

Maselli, F., Romanelli, S., Bottai, L., Zipoli, G., 2003. Use of NOAA-AVHRR NDVI images for the estimation of dynamic fire risk in Mediterranean areas. Remote Sensing of Environment 86, 187-197.

Maselli, F., Rodolfi, A., Bottai, L., Romanelli, S., Conese, C, 2000. Classification of Mediterranean vegetation by TM and ancillary data for the evaluation of fire risk. International Journal of Remote Sensing 17, 3303-3313.

McArthur, A.G., 1966. Weather and grassland fire behaviour. Australian Forestry and Timber Bureau Leaflet, no. 100

McArthur, A.G., 1967. Fire behaviour in eucalypt forests. Australian Forestry and Timber Bureau Leaflet, no. 107.

McGinnis, D.F., Tarpley, J.D., 1985. Vegetation cover mapping from NOAA/AVHRR. Advances in Space Research 5, 359-369.

Merrill, D.F., Alexander, M.E., 1987. Glossary of Forest Fire Management Terms, fourth edn. National Research Council of Canada, Canadian Committee on Forest Fire Management, Ottawa, Ontario.

Miller, J.D., Danzer, S.R., Watts, J.M., Stone, S., Yool, S.R., 2003. Cluster analysis of structural stage classes to map wildland fuels in a Madrean ecosystem. Journal of Environmental Management 68, 239-252

Morsdorf, F., Meier, E., Kdtz, B., Itten, K.I., Dobbertin, M., Allgower, B., 2004. LIDARbased geometric reconstruction of boreal type forest stands at single tree level for forest and wildland fire management. Remote Sensing of Environment 92, 353-362. 
Mutlu, M., Popescu, S.C., Stripling, C, Spencer, T., 2008. Mapping surface fuel models using lidar and multispectral data fusion for fire behavior. Remote Sensing of Environment 112, 274-285

Neeff, T., Dutra, L.V., dos Santos, J.R., Freitas, CD., Araujo, L.S., 2003. Tropical forest stand table modelling from SAR data. Forest Ecology and Management 186, 159-170.

Noble, I.R., 1980. McArthur's fire-danger meters expressed as equations. Australian Journal of Ecology 5, 201-203.

Ottmar, R.D., Sandberg, D.V., Riccardi, C.L., Prichard, S.J., 2007. An overview of the fuel characteristics classification system-quantifying, classifying, and creating fuelbeds for resource planning. Canadian Journal of Forest Research 37, 23832393.

Pausas, J.G., Vallejo, V.R., 1999. The role of fire in European Mediterranean ecosystems. In: Chuvieco, E. (Ed.), Remote Sensing of Large Wildfires. Springer, Berlin, pp. 3-16.

Pesonen, A., Maltamo, M., Eerikainen, K., Packalen, P., 2008. Airborne laser scanningbased prediction of coarse woody debris volumes in a conservation area. Forest Ecology and Management 255, 3288-3296.

Popescu, S.C., Zhao, K., 2008. A voxel-based lidar method for estimating crown base height for deciduous and pine trees. Remote Sensing of Environment 112, 767 781.

Poulos, H.M., Camp, A.E., Gatewood, RG., Loomis, L., 2007. A hierarchical approach for scaling forest inventory and fuels data from local to landscape scales in the Davis Mountains, Texas, USA. Forest Ecology and Management 244, 1-15.

Puissant, A., Hirsch, J., Weber, C, 2005. The utility of texture analysis to improve perpixel classification for high to very high spatial resolution imagery. International Journal of Remote Sensing 26, 733-745.

Pyne, S.J., Andrews, P.L, Laven, R.D., 1996. Introduction to Wildland Fire, second edn. John Wiley \& Sons, Inc., New York.

Ranson, K.J., Lang, R.H., Chauhan, N.S., Cacciola, R.J., Kilic, O., Guoqing, S., 1997. Mapping of boreal forest biomass from spaceborne synthetic aperture radar. Journal of Geophysical Research 102, 29599-29610.

Riano, D., Chuvieco, E., Salas, F.J., Palacios-Orueta, A., Bastarrica, A., 2002. Generation of fuel type maps from LandsatTM images and ancillary data in Mediterranean ecosystems. Canadian Journal of Forest Research 32, 1301-1315.

Riano, D., Meier, E., Allgower, B., Chuvieco, E., Ustin, S.L., 2003. Modeling airborne laser scanning data for the spatial generation of critical forest parameters in fire behavior modeling. Remote Sensing of Environment 86, 177-186.

Riano, D., Chuvieco, E., Condes, S., Gonzalez-Matesanz, J., Ustin, S.L., 2004. Generation of crown bulk density for Pinus sylvestris L. from lidar. Remote Sensing of Environment 92, 345-352.

Riano, D., Chuvieco, E., Ustin, S.L., Salas, F.J., Rodriguez-Perez, J.R., Ribeiro, L.M., Viegas, D.X., Moreno, J.F., Fernandez, H., 2007. Estimation of shrub height for fuel-type mapping combining airborne LiDAR and simultaneous color infrared ortho imaging. International Journal of Wildland Fire 16, 341-348.

Roberts, D.A., Green, R.O., Adams, J.B., 1997. Temporal and spatial patterns in vegetation and atmospheric properties from AVIRIS. Remote Sensing of Environment $62,223-240$.

Roberts, D.A., Gardner, M., Church, R., Ustin, S., Scheer, G., Green, RO., 1998. Mapping chaparral in the Santa Monica Mountains using multiple endmember spectral mixture models. Remote Sensing of Environment 65, 267-279.

Roberts, D.A., Dennison, P.E., Gardner, M.E., Hetzel, Y., Ustin, S.L., Lee, C.T., 2003 Evaluation of the potential of Hyperion for fire danger assessment by comparison to the airborne visible/infrared imaging spectrometer. IEEE Transactions on Geoscience and Remote Sensing 41, 1297-1310.

Rollins, M.G., Keane, R.E., Parson, R.A., 2004. Mapping fuels and fire regimes using remote sensing, ecosystem simulation, and gradient modeling. Ecological Applications 14, 75-95

Rothermel, R.C., 1972. A mathematical model for predicting fire spread in wildland fuels. Rep. No. RP INT-115. SDA Forest Service, Ogden, UT.

Saatchi, S., Halligan, K., Despain, D.G., Crabtree, R.L., 2007. Estimation of forest fuel load from radar remote sensing. IEEE Transactions on Geoscience and Remote Sensing 45, 1726-1740.
Salas, F.J., Chuvieco, E., 1995. Aplicacion de imagenes Landsat-TM a la cartografia de modelos de combustible. Revista de Teledeteccion 5, 18-28.

Sandberg, D.V., Ottmar, R.D., Cushon, G.H., 2001. Characterizing fuels in the $21 \mathrm{st}$ Century. International Journal of Wildland Fire 10, 381-387.

Sawaya, K.E., Olmanson, L.G., Heinert, N.J., Brezonik, P.L., Bauer, M.E., 2003. Extending satellite remote sensing to local scales: land and water resource monitoring using high-resolution imagery. Remote Sensing of Environment 88, 144-156.

Scott, J.H., 1999. NEXUS: a system for assessing crown fire hazard. Fire Management Notes 59, 20-24

Scott, J.H., Burgan, R., 2005. Standard fire behavior fuel models: a comprehensive set for use with Rothermel's surface fire spread model. Rep. No. RMRS GTR-153. Rocky Mountain Research Station, Fort Collins, CO.

Scott, K, Oswald, B., Farrish, K, Unger, D, 2002. Fuel loading prediction models developed from aerial photographs of the Sangre de Cristo and Jemez mountains of New Mexico, USA. International Journal of Wildland Fire 11, 85-90.

Show, S.B., Kotok, E.I., 1929. Cover type and fire control in the national forests of northern California. Rep. No. 1495. USDA, Forest Services, Washington, DC.

Sirakoff, C, 1985. A correction to the equations describing the McArthur forest fire danger meter. Australian Journal of Ecology 10, 481.

Skowronski, N., Clark, K, Nelson, R, Horn, J., Patterson, M., 2007. Remotely sensed measurements of forest structure and fuel loads in the Pinelands of New Jersey. Remote Sensing of Environment 108, 123-129.

Slatton, K.D., Crawford, M.M., Evans, B.L., 2001. Fusing interferometric radar and laser altimeter data to estimate surface topography and vegetation heights. IEEE Transactions on Geoscience and Remote Sensing 39, 2470-2482.

Smith-Jonforsen, G., Folkesson, K., Hallberg, B., Ulander, L.M.H., 2007. Effects of forest biomass and stand consolidation on P-band backscatter. Ieee Geoscience and Remote Sensing Letters 4, 669-673.

Sneeuwjagt, R.J., Pee, G.B., 1985. Forest fire Behaviour Tables for Western Australia. Department of Conservation and Land Management.

Suarez, J.C., Ontiveros, C, Smith, S., Snape, S., 2005. Use of airborne LiDAR and aerial photography in the estimation of individual tree heights in forestry. Computers \& Geosciences 31, 253-262.

Toutin, T., Amaral, S., 2000. Stereo RADARSAT data for canopy height in Brazilian forest. Canadian Journal of Remote Sensing 26, 189-199.

Ustin, S.L, Roberts, D.A., Gamon, J.A., Asner, G.P., Green, R.O., 2004. Using imaging spectroscopy to study ecosystem processes and properties. BioScience 54,523534.

van Coillie, F.M.B., Verbeke, L.P.C., De Wulf, R.R., 2007. Feature selection by genetic algorithms in object-based classification of IKONOS imagery for forest mapping in Flanders, Belgium. Remote Sensing of Environment 110, 476-487.

van der Sande, C.J., de Jong, S.M., de Roo, A.P.J., 2003. A segmentation and classification approach of IKONOS-2 imagery for land cover mapping to assist flood risk and flood damage assessment. International Journal of Applied Earth Observation and Geoinformation 4, 217-229.

van Wagner, C.E., 1987. Development and structure of the Canadian forest fire weather index system. Rep. No. Forest Technology Report 35. Canadian Forestry Service, Ottawa.

van Wagner, C.E., Pickett, T.L, 1985. Equations and FORTRAN program for the Canadian Forest Fire Weather Index System. Rep. No. Forestry Technical Report 33. Canadian Forestry Service, Ottawa.

van Wagtendonk, J.W., Root, R.R., 2003. The USE of multitemporal Landsat normalized difference vegetation index (NDVI) data for mapping fuels models in Yosemite National Park, USA. International Journal of Remote Sensing 24 1639-1651

Varga, T.A., Asner, G.P., 2008. Hyperspectral and lidar remote sensing of fire fuels in Hawaii Volcanoes National Park. Ecological Applications 18, 613-623.

Wang, L., Sousa, W.P., Gong, P., Biging, G., 2004. Comparison of IKONOS and QuickBird images for mapping mangrove species on the Caribbean coast of Panama. Remote Sensing of Environment 91, 432-440.

Wilson, B.A., Ow, C.F.Y., Heathcott, M., Milne, D., McCaffrey, T.M., Ghitter, G., Franklin, S.E., 1994. Landsat MSS classification of fire fuel types in Wood Buffalo National Park. Global Ecology and Biogeography Letters 4, 33-39. 